Pacific Journal of Mathematics

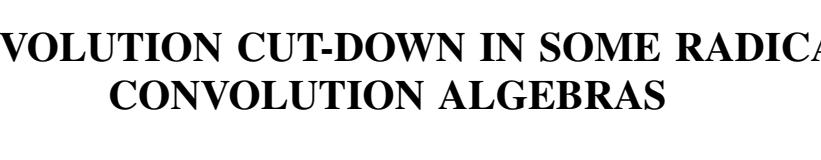




\title{
CONVOLUTION CUT-DOWN IN SOME RADICAL CONVOLUTION ALGEBRAS
}

\author{
LEE A. RUBEL
}

Let $\mathscr{A}=L_{1 \mathrm{oc}}^{1}\left(\boldsymbol{R}^{+}\right)$be the algebra of locally integrable functions on the positive real axis, with convolution as multiplication, given by

$$
(f * g)(x)=\int_{0}^{x} f(x-t) g(t) d t .
$$

Sometimes it is convenient to think of our functions as being defined on all of $R$, but vanishing for negative $x$. We are interested in subalgebras of $\mathscr{A}$ that are Banach algebras in some norm, and that are radical in the sense that there exist no (nontrivial) complex homomorphisms. We call these algebras radical convolution algebras. Such algebras $A$ present a challenge because there is no Fourier transform for them.

We are concerned with the problem of "convolution cutdown"; namely whether given a radical convolution algebra $A$ and an $f \in A$, there must exist an $h \in A(h \neq 0$ such that $f * h \in L^{1}\left(\boldsymbol{R}^{+}\right)$. We show, at least, that one cannot always choose $h \in L^{1}$. As a corollary, we show that simultaneous convolution cut-down is not always possible.

A class of examples is formed by certain Beurling algebras $A_{w}=L_{w}^{1}\left(\boldsymbol{R}^{+}\right)$, where $w$ is a positive weight function that satisfies

$$
w(x+y) \leqq w(x) w(y)
$$

and where

$$
\|f\|=\int_{0}^{\infty}|f(t)| w(t) d t
$$

It is not hard to show that for $A_{w}$ to be a radical algebra, it is necessary and sufficient that

$$
[w(x)]^{1 / x} \longrightarrow 0 \text { as } x \rightarrow+\infty .
$$

For example, we could choose $w(x)=\exp \left(-x^{\alpha}\right)$ for any $\alpha>1$. (Note that the restriction, assumed by many authors, that $w(x) \geqq 1$, certainly does not apply here.)

Problem. Given a radical convolution algebra $A$ and an $f$ in $A$, does there exist an $h$ in $A(h \neq 0)$ such that $f * h \in L^{1}$ ?

This problem arose in discussion with Jamil A. Siddiqi, whom the author thanks for his help. An affirmative answer to the pro- 
blem would be useful in solving certain natural problems about the ideal structure of $A$. To tell the truth, an affirmative answer is hardly to be expected, since convolution is known as a smoothing operator, and not as a reducing operator. We cannot at present prove a general negative answer. At least for some nonradical algebras, a negative answer is furnished by studying the distribution of the zeros of the Fourier transforms. We provide a partial negative solution in the radical case.

From now on, we assume that $A$ is a radical convolution algebra, and we discard the function identically 0 .

THEOREM. It is not the case that for every $f \in A$ there is a $g \in L^{1}$ such that $f * g \in L^{1}$.

CoROLlaRY. There exists a pair $f, g \in A$ such that for no $h \in L^{1}$ are both $f * h$ and $g * h$ in $L^{1}$.

We summarize this by saying that simultaneous convolution cut-down is impossible.

Proof of corollary. We proceed by contradiction. Given $f \in A$, choose $g \in A$ so that $f * g \in L^{1}$. Now choose $h \in A$ so that $g * h \in L^{1}$ and $(f * g) * h \in L^{1}$. Then with $k=g * h$, we would have $f * k \in L^{1}$ where $k \in L^{1}$, which contradicts the theorem.

Proof of theorem. We observe that for a function $h \in L^{1}\left(\boldsymbol{R}^{+}\right)$, its Fourier transform

$$
h^{\wedge}(x)=\int_{0}^{\infty} e^{-i t x} f(t) d t
$$

has a natural extension as a function holomorphic in the lower half-plane $L=\{z: \operatorname{Im} z<0\}$. If now $f * g=h$ with $g, h \in L^{1}\left(\boldsymbol{R}^{+}\right)$, we define for every $z \in L$ :

$$
V_{z} f=\operatorname{ord}_{z} h^{\wedge}-\operatorname{ord}_{z} g^{\wedge}
$$

where $\operatorname{ord}_{z} H$ is the order of the zero of $H$ at the point $z$. It is easy to see that $V_{z}$ is well defined, for if $f * g=h$ and $f * G=H$ then $f *(g * H-G * h)=0$ and by the famous Titchmarsh theorem that there are no divisors of zero in $\mathscr{A}$, we have $g * H-G * h=0$, etc. Roughly, $V_{z}$ plays the role of "the order of vanishing at $z$ of the Fourier transform of $f$ ". Now it is easy to see that $V_{z}$ extends to a valuation on the field $A / A$ of formal quotients of functions in $A$. (That $A / A$ makes sense as a field follows from the Titchmarsh theorem.)

By "valuation" we mean that 


$$
\begin{gathered}
V_{z} f g=V_{z} f+V_{z} g \\
V_{z}(f+g) \geqq \min \left(V_{z} f, V_{z} g\right) .
\end{gathered}
$$

We appeal now to a theorem of Royden ([2], Proposition 5, p. 274 ) that any valuation $V$ on $A / A$ must be nonnegative on $A$. When applied to $V_{z}$, this implies that $h^{\wedge} / g^{\wedge}$ has no pole at $\approx$. If we now let

$$
\dot{\phi}_{z} f=\frac{h^{\wedge}(z)}{g^{\wedge}(z)}
$$

then it follows that $\phi_{z}$ is a complex homomorphism of $A$. Since $A$ is assumed to be radical, $\phi_{z} f=0$, and thus $h^{\wedge}(z)=0$ for all $z \in L$.

Therefore, by a simple argument, $h^{\wedge}(x)$ vanishes for all real $x$, and consequently $h=0$, which is not allowed. This contradiction proves the theorem.

\section{REFERENCES}

1. A. Beurling, Sur les intégrales de Fourier absolument convergentes et leur application á une transformation fonctionelle, Ninth Congress of Scandinavian Mathematicians, Helsinki, 1938.

2. H. Royden, Rings of analytic and meromorphic functions, Trans. Amer. Math. Soc., 83 (1956), 269-276.

Received August 17, 1978. The author's research was partially supported by grants from the National Science Foundation.

UNIVERSITY OF ILLINOIS AT URBANA-ChAMPAIGN

URBANA, IL 61801 



\section{PACIFIC JOURNAL OF MATHEMATICS}

\section{EDITORS}

Donald BABBITT (Managing Editor)

University of California

Los Angeles, CA 90024

HUGo RossI

University of Utah

Salt Lake City, UT 84112

C. C. MOORE and ANDREW OGG

University of California

Berkeley, CA 94720

\section{J. DuGUNDJI}

Department of Mathematics

University of Southern California

Los Angeles, CA 90007

R. FINN and J. Milgram

Stanford University

Stanford, CA 94305

ASSOCIATE EDITORS
E. F. BECKENBACH
B. H. NeumanN
F. WOLF
K. YoSHIDA

\section{SUPPORTING INSTITUTIONS}

\author{
UNIVERSITY OF BRITISH COLUMBIA \\ CALIFORNIA INSTITUTE OF TECHNOLOGY \\ UNIVERSITY OF CALIFORNIA \\ MONTANA STATE UNIVERSITY \\ UNIVERSITY OF NEVADA, RENO \\ NEW MEXICO STATE UNIVERSITY \\ OREGON STATE UNIVERSITY \\ UNIVERSITY OF OREGON
}

\author{
UNIVERSITY OF SOUTHERN CALIFORNIA \\ STANFORD UNIVERSITY \\ UNIVERSITY OF HAWAII \\ UNIVERSITY OF TOKYO \\ UNIVERSITY OF UTAH \\ WASHINGTON STATE UNIVERSITY \\ UNIVERSITY OF WASHINGTON
}

The Supporting Institutions listed above contribute to the cost of publication of this Journal, but they are not owners or publishers and have no responsibility for its content or policies.

Mathematical papers intended for publication in the Pacific Journal of Mathematics should be in typed form or offset-reproduced, (not dittoed), double spaced with large margins. Please do not use built up fractions in the text of the manuscript. However, you may use them in the displayed equations. Underline Greek letters in red, German in green, and script in blue. The first paragraph or two must be capable of being used separately as a synopsis of the entire paper. Please propose a heading for the odd numbered pages of less than 35 characters. Manuscripts, in triplicate, may be sent to any one of the editors. Please classify according to the scheme of Math. Reviews, Index to Vol. 39. Supply name and address of author to whom proofs should be sent. All other communications should be addressed to the managing editor, or Elaine Barth, University of California, Los Angeles, California, 90024.

50 reprints to each author are provided free for each article, only if page charges have been substantially paid. Additional copies may be obtained at cost in multiples of 50 .

The Pacific Journal of Mathematics is issued monthly as of January 1966. Regular subscription rate: $\$ 84.00$ a year (6 Vols., 12 issues). Special rate: $\$ 42.00$ a year to individual members of supporting institutions.

Subscriptions, orders for numbers issued in the last three calendar years, and changes of address should be sent to Pacific Journal of Mathematics, P.O. Box 969, Carmel Valley, CA 93924, U.S.A. Older back numbers obtainable from Kraus Periodicals Co., Route 100, Millwood, NY 10546.

PUBLISHED BY PACIFIC JOURNAL OF MATHEMATICS, A NON-PROFIT CORPORATION

Printed at Kokusai Bunken Insatsusha (International Academic Printing Co., Ltd.). 8-8, 3-chome, Takadanobaba, Shinjuku-ku, Tokyo 160, Japan.

Copyright (C) 1979 by Pacific Journal of Mathematics Manufactured and first issued in Japan 


\section{Pacific Journal of Mathematics}

\section{Vol. 82 , No. 2 \\ February, 1979}

Krishnaswami Alladi and Paul Erdős, On the asymptotic behavior of large prime

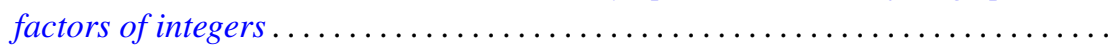

Alfred David Andrew, A remark on generalized Haar systems in $L_{p}$,

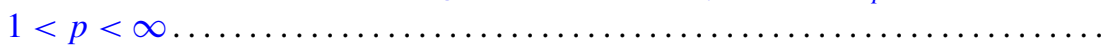

John M. Baker, A note on compact operators which attain their norm . . ........

Jonathan Borwein, Weak local supportability and applications to

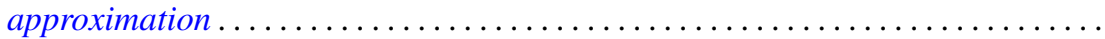

Tae Ho Choe and Young Soo Park, Wallman's type order compactification ........

Susanne Dierolf and Ulrich Schwanengel, Examples of locally compact

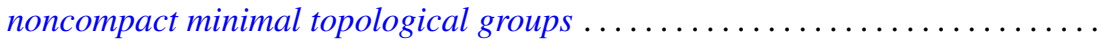

Michael Freedman, A converse to (Milnor-Kervaire theorem) $\times R$ etc. . . . . . . .

George Golightly, Graph-dense linear transformations ..................

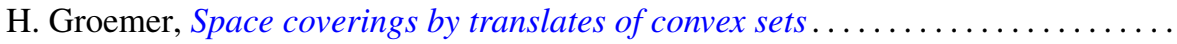

Rolf Wim Henrichs, Weak Frobenius reciprocity and compactness conditions in

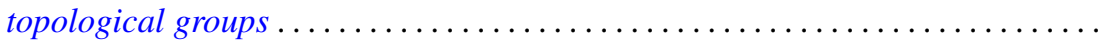

Horst Herrlich and George Edison Strecker, Semi-universal maps and universal

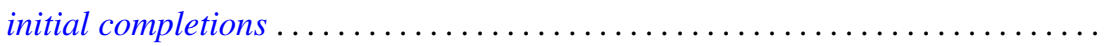

Sigmund Nyrop Hudson, On the topology and geometry of arcwise connected,

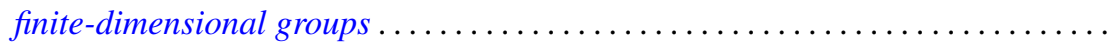

K. John and Václav E. Zizler, On extension of rotund norms. II .............

Russell Allan Johnson, Existence of a strong lifting commuting group of transformations. II.

Bjarni Jónsson and Ivan Rival, Lattice varieties covering the smallest nonmodular variety

Grigori Abramovich Kolesnik, On the order of Dirichlet L-functions .

Robert Allen Liebler and Jay Edward Yellen, In search of nonsolvable groups of

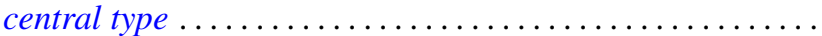

Wilfrido Martínez T. and Adalberto Garcia-Maynez Cervantes, Unicoherent plane Peano sets are $\sigma$-unicoherent ...

M. A. McKiernan, General Pexider equations. I. Existence of injective

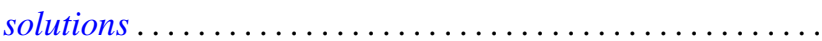

M. A. McKiernan, General Pexider equations. II. An application of the theory of webs.

Jan K. Pachl, Measures as functionals on uniformly continuous functions . .

Lee Albert Rubel, Convolution cut-down in some radical convolution algebras ...

Peter John Slater and William Yslas Vélez, Permutations of the positive integers

with restrictions on the sequence of differences. II . . .

Raymond Earl Smithson, A common fixed point theorem for nested spaces ....

Indulata Sukla, Generalization of a theorem of McFadden .... . . .

Jun-ichi Tanaka, A certain class of total variation measures of analytic measures.

Kalathoor Varadarajan, Modules with supplements .............. 